\title{
ANALYSIS OF CONFLICT RESOLUTION IN PHYSICAL EDUCATION DEPENDING ON A TEACHER'S GENDER
}

\author{
Jože Štihec, Mateja Videmšek, Saša Vrbnjak*
}

\author{
Faculty of Sport, University of Ljubljana, Ljubljana, Slovenia \\ * Independent researcher, Slovenia
}

Submitted in August, 2010

BACKGROUND: Although many studies about conflict handling and resolution have so far been conducted, only a limited number of them have delved into the sphere of physical education. The specific nature of work with physical education in certain situations intensifies the occurrence of conflicts. The teacher as an expert in the educational process can, in such cases, provide a good example of how to handle a specific conflict.

OBJECTIVE: The study aimed to gather information about differences in the resolving of conflict situations which arise during the physical education process between male and female physical education teachers in terms of which conflict resolution strategy they selected and how consistently they applied them.

METHODS: For this purpose 158 physical education teachers from randomly selected Slovenian primary schools were surveyed (78 men and 80 women, aged 28-60 years) in April 2010. Teachers at selected schools volunteered to take part in the study and their participation was anonymous. A questionnaire (Bežek, 2000; Štihec, Bežek, Videmšek, \& Karpljuk, 2004) with 17 questions was used. The frequencies of responses were calculated. The $\chi^{2}$ test was applied at a $5 \%$ risk level $(\mathrm{p} \leq 0.05)$ to verify whether there were any differences between male and female physical education teachers in terms of selecting a conflict resolution strategy.

RESULTS: It was established that teachers use various approaches to resolving conflict situations. Most often they take an authoritarian approach ("insisting on one's own opinion"). Statistically significant differences were identified between the results of the male and female physical education teachers in some pedagogical situations in terms of choosing a conflict resolution strategy.

CONCLUSIONS: The teachers mainly approach the resolving of conflict situations by "insisting on their own opinion". In the course of resolving a conflict, inconsistencies often occur but are mainly the consequence of the desire to ensure an efficient and the fastest possible elimination of the conflict behaviour. It was also established that in some cases the male physical education teachers differed from their female counterparts in terms of which conflict resolution strategies they selected. In further research some other factors, such as the teacher's age, cultural environment, the teacher's target orientation, the teacher's emotional intelligence and leadership styles could be analysed.

Keywords: Primary school, physical education, conflicts, male and female physical education teachers.

\section{INTRODUCTION}

School is a place where it is not only teachers and pupils who interact, because interpersonal relationships also develop between teachers and parents, amongst teachers, amongst pupils and also between teachers and the school management. Yet it is true that the relationship between the teacher and the pupil is the most exposed one (Bowman, 2005), constituting a basic element of education (Brajša, 1995). Apart from the professional relationship there is also a personal relationship between the two, and the emotional component is strongly attached to this rational core, thus contributing to a positive emotional climate which is necessary for spontaneous interaction. This interaction between the two consists of cooperation, mutual influence and one's communication with the other, which sometimes leads to conflict situations. Such disagreements have various roots ranging from discipline and assessment to the (in)appropriate delivery of learning materials, and can arise from intrapersonal or interpersonal conflicts with teachers and pupils alike, etc. All of the above also applies to the pedagogical process in physical education where the specific nature of work in certain situations intensifies the occurrence of conflicts (Štihec, 1994; Štihec, Bežek, Videmšek, \& Karpljuk, 2004).

The complexness of the conflicts was described by Anderson, Foster Kuehn and McKinney (1996) in a joint definition. They believe that the key role is played by individuals with all their complexity - both conscious and subconscious - interacting with each other, yet pursuing different mutually uncoordinated goals (Anderson, Foster Kuehn, \& McKinney, 1996). Kržišnik (2004) reported something similar, defining conflict as a situation 
featuring two vital elements: a conflict of interest and interdependence. The participants in a conflict strive to take different directions because of different subjective interests and priorities (Gross \& Guererro, 2000), yet they are bound by this interdependence which prevents them from taking their own paths since the choice made by one of them would limit the choice made by the other and vice versa (Kržišnik, 2004). Theory abounds with different definitions of the notion of conflict. Many other definitions exist, yet the common denominator of all of the abovementioned definitions offered by different authors is that conflicts stem from the differing interests and goals of individuals or groups and from the hindered achievement of these goals.

\section{Conflicts in physical education}

Physical education in all kind of schools (451 primary, 158 secondary) in Slovenia is compulsory. Pupils in primary schools have three lessons per week, each lesson takes 45 minutes. Lessons are conducted by physical education teachers - they are specialists only in physical education (this one subject is studied for 5 years). Physical education in all schools is divided by pupils' gender. Male pupils have male teachers, female pupils have female teachers. Each physical education teacher has a group of a maximum of 20 pupils.

In the physical education process, the specific nature of work in certain situations may intensify the occurrence of conflicts (Štihec, 1994; Štihec, Bežek, Videmšek, \& Karpljuk, 2004). While doing their work, in terms of what can lead to a conflict situation, physical education teachers often have to cope with a lack of discipline, excessive boisterousness, failure to follow the instructions, unauthorised absences, pupils' lack of motivation, potentially dangerous situations/activities for pupils, etc. It is true that physical education classes are less formal than other subjects requiring someone to peacefully sit at a desk (Štihec, 1994), nevertheless, the greater freedom of movement during physical education classes should not be a reason for creating situations leading to conflicts. Due to the specificity of this work (noise, pupils' distance, a dynamic pedagogical process, etc.) the causes of conflicts can also be related to the problem of communication in the physical education process. The problem of communication, both verbal and non-verbal, can arise on the side of the teacher or the pupil. Non-verbal communication is therefore even more important than during other classes which also play their part in the education process at school. The secret of successful interpersonal communication in physical education thus lies in achieving harmony between verbal and non-verbal messages.

\section{Resolving conflict situations}

Researchers in different academic areas have developed different theories and approaches to handling conflicts (Tolar \& Katz Jameson, 2006). Gordon (1981) advocates the conflict resolution method where there is no loser and both sides strive to find a solution which ensures that nobody ends up a loser. A modification of Gordon's conflict resolution method was developed by Robbins (1989). He distinguishes between four methods: the first is based on "insisting on one's own opinion", the second is the adjustment method, the third consists of a compromise, while the fourth is cooperation. Deutsch (1976) describes only two types of conflict handling behaviour: cooperation and competition. Rus (1994) believes that conflicts can be resolved using confrontation, negotiation, mediation or arbitration. Glasser (1994) states the methods of avoidance, adjustment, competition and cooperation. Horvat (1998) establishes that, despite the various names and different numbers of conflict resolution methods reported by various authors, these methods can be divided into two large groups: the first group includes those working on the principle of power and bringing satisfaction only to one side, whereas the second group consists of methods satisfying and benefiting all participants.

Teachers in schools resort to different conflict resolution methods (Bjekić \& Zlatić, 2006; Mahon, 2009) and this has also been established for physical education teachers (Štihec, Bežek, Videmšek, \& Karpljuk, 2004). It is the resolution strategy that is crucial since a conflict can serve as a very effective educational element (Brajša, 1993). In his studies, Gordon (1992) finds that teachers in schools mainly take two approaches, with both being based on the "win or lose" principle. It is relatively rare for teachers to use one method only and they tend to use both of them, depending on the situation. However, this switching between methods only puzzles the pupils and they never know which restrictions apply on which day. This does not constitute a sincere democratic approach whereby the teacher truly considers and respects the pupil's needs (Bežek, 2000). However, to ensure efficient conflict resolution in physical education the teacher must employ different approaches. Which approach the teacher will use in a specific situation depends on them personally, their qualities and mood as well as on the pupils, the environment and the particular situation (Štihec, Videmšek, Karpljuk, Bežek, Šebjan, \& Vrbnjak, 2007).

Robbins modifies Gordon (1992) by defining four methods of conflict handling. These methods are similar to those above, differing only in terms of an additional variant where both participants in the conflict are satisfied even though the result is not ideal for either of them (Brajša, 1993).

In our study a survey was used to establish how the participating Slovenian physical education teachers react to specific hypothetical conflict situations divided into several pedagogical situations. We were interested in how they resolve those conflicts which could result 
in pupils' injuries and are therefore dangerous, conflicts hindering or thwarting the conduct of the pedagogical process and conflicts arising from pupils' differing interests. The aim was to establish which conflict resolution method is most frequently applied by Slovenian physical education teachers. We also asked them to evaluate themselves whether they are consistent in the way they resolve conflict situations. We were also interested in whether there were any differences between male and female physical education teachers in terms of which conflict resolution strategy they selected.

\section{METHODS}

\section{Participants}

The survey included 158 physical education teachers ( 78 men and 80 women, aged 28-60 years) from 43 randomly selected primary schools in Slovenia. The teachers at selected schools volunteered to take part in the study and their participation was anonymous. The questionnaire was given to all participants (separately at each school) and collected after 45 minutes. Each questionnaire was checked to make sure that it was properly completed (all questions must have answers). The survey was conducted in April 2010.

All personal data were acquired in compliance with the Personal Data Protection Act (Official Gazette of the Republic of Slovenia, no. 59/1999). The sample was not representative and does not allow for generalisation of the results.

\section{Instruments and procedure}

The sample of variables in the non standardized questionnaire with 17 questions (Bežek, 2000; Štihec, Bežek, Videmšek, \& Karpljuk, 2004) used for surveying physical education teachers was based on a thesis by Robbins (Brajša, 1993) who ranked possible conflict resolution methods into four classes.

1. Insisting on one's own opinion - the teacher insists on enforcing their needs. They are convinced that their opinion is the only correct one and their solutions the only ones that are acceptable.

2. Yielding - the teacher adjusts to the desires and needs of pupils and does not enforce their own desires.

3. Compromise - this includes voting; this time this, the next time that; both the teacher and the pupil yield.

4. Cooperation - involving an explanation of one's own opinion and listening to the other person's opinion; a mutual agreement which satisfies everyone.

Possible responses to each question, reflecting the selected approach to conflict resolution, were as follows: insisting on one's own opinion, yielding, compromise, cooperation and consistency. In each question which illustrated a hypothetical conflict situation, the teachers circled the approach (1, 2, 3 or 4$)$ corresponding to their method of solving this type of conflict in the physical education process. These hypothetical conflicts were divided into several sets of pedagogical situations such as, for example, conflicts which can cause injuries during the physical education process, conflicts which disturb the conduct of the pedagogical process, conflicts resulting from the differing interests of individual pupils etc.

\section{Methods of processing the statistical data}

The data were processed with the SPSS 18.0 statistical software package. The frequencies of responses were calculated. The $\chi^{2}$ test was applied at a $5 \%$ risk level ( $p \leq 0.05)$ to verify whether there were any differences between the male and female physical education teachers in terms of selecting a conflict resolution strategy.

\section{RESULTS}

To ensure the better transparency of results, individual questions in the questionnaire were combined in three thematically related sets covering:

- physical education teachers' reaction to dangerous situations in the physical education process;

- physical education teachers' reaction to situations disturbing the physical education process;

- teacher's consistency in resolving individual conflict situations.

Physical education teachers' reactions to dangerous situations in the physical education process

In situations which could be dangerous (TABLE 1) the teachers mainly resort to resolving conflicts using the "insisting on one's own opinion" approach. The pupils often overestimate their abilities and are driven by a desire to prove themselves. The feeling of danger is pushed aside. Teachers' judgment about this is more rational. Whether they will take the time to discuss this with their pupils or not is a matter of their judgment (depending on the seriousness of the situation, the pupil and other circumstances).

One of the principles of communication comfort (Brajša, 1993) is the right to be active and passive during a conversation. Everyone has the right to take part in or withdraw from a conversation. In relation to this, it is also worth mentioning the motivation to resolve a conflict. Sometimes pupils do not want to resolve a conflict together with the teacher at all. On the other hand, their behaviour puts them and other pupils in danger. The teacher who is responsible for safety in the gym is therefore forced to employ the "power" method. Gordon 
(1992) believes that, when a fast and decisive reaction is required or when a large group of people is involved, the "power" method (whereby the teacher insists on their own opinion) is the only efficient one. However, the absence of conflict behaviour as such does not mean that the conflict has been successfully resolved. The undesired behaviour could be repeated. It is thus reasonable to consider cooperation with the pupil involved (Mahon, 2009), of course at a convenient time.

Physical education teachers' reactions to situations disturbing the physical education process

In situations disturbing the pedagogical process, consuming time and reducing the efficiency of the class, the most frequently applied approaches include the teacher insisting on their own opinion, the teacher seeking to reach a compromise as well as to cooperate with the pupil (TABLE 2). Male teachers are prone to the solution where they insist on their own opinion while female teachers most often choose a cooperation strategy.

\section{Teachers' consistency in resolving individual conflict si- tuations}

Some questions in the survey questionnaire enquired about how consistent teachers are in selecting a strategy to resolve individual conflict situations.

The number of those teachers who use the same conflict resolution approach is slightly higher than the number of inconsistent teachers (TABLE 3). This is true for both male and female teachers. Female teachers are

TABLE 1

Conflict resolution in dangerous situations

\begin{tabular}{|l|c|c|c|c|}
\cline { 2 - 5 } \multicolumn{1}{c|}{} & \multicolumn{2}{c|}{ Male teachers } & \multicolumn{2}{c|}{ Female teachers } \\
\hline Teacher's reaction to dangerous situations & Number of responses & \% of responses & Number of responses & \% of responses \\
\hline The teacher insists on his/her own opinion & 224 & 71.79 & 236 & 73.75 \\
\hline The teacher yields & 0 & 0.00 & 0 & 0.00 \\
\hline The teacher seeks a compromise & 40 & 12.82 & 16 & 5.00 \\
\hline The teacher cooperates with the pupil & 48 & 15.39 & 68 & 21.25 \\
\hline Total & 312 & 100.00 & 320 & 100.00 \\
\hline
\end{tabular}

Legend: Number of male teachers -78 , Number of female teachers -80 , Number of analysed questions in this category -4

TABLE 2

Conflict resolution in situations disturbing the pedagogical process

\begin{tabular}{|l|c|c|c|c|}
\cline { 2 - 5 } \multicolumn{1}{c|}{} & \multicolumn{2}{c|}{ Male teachers } & \multicolumn{2}{c|}{ Female teachers } \\
\hline Teacher's reaction to situations disturbing the class & Number of responses & \% of responses & Number of responses & \% of responses \\
\hline The teacher insists on his/her own opinion & 236 & 43.22 & 174 & 31.07 \\
\hline The teacher yields & 22 & 4.03 & 16 & 2.86 \\
\hline The teacher seeks a compromise & 154 & 28.21 & 164 & 29.28 \\
\hline The teacher cooperates with the pupil & 134 & 24.54 & 206 & 36.79 \\
\hline Total & 546 & 100.00 & 560 & 100.00 \\
\hline
\end{tabular}

Legend: Number of male teachers -78 , Number of female teachers -80 , Number of analysed questions in this category -7

TABLE 3

Teachers' consistency in using conflict resolution methods

\begin{tabular}{|l|c|c|c|c|}
\cline { 2 - 5 } \multicolumn{1}{c|}{} & \multicolumn{2}{c|}{ Male teachers } & \multicolumn{2}{c|}{ Female teachers } \\
\hline Conflict resolution method & Number of responses & \% of responses & Number of responses & \% of responses \\
\hline Consistent & 208 & 53.33 & 230 & 57.50 \\
\hline Inconsistent & 182 & 46.67 & 170 & 42.50 \\
\hline Total & 390 & 100.00 & 400 & 100.00 \\
\hline
\end{tabular}

Legend: Number of male teachers -78 , Number of female teachers -80 , Number of analysed questions in this category -5 
slightly more consistent than male teachers. Other authors have reported similar results with a Slovenian sample of physical education teachers (Bežek, 2000; Śtihec et al., 2007). This inconsistency mainly stems from the adjustment of the conflict resolution approach to individual pupils and also from exceptional, unforeseeable causes beyond our influence. Every pupil is unique and the use of different approaches with different pupils can be justifiable in terms of a fast and effectively resolved conflict (Weitzman \& Weitzman, 2000). However, such decisions may give rise to new conflicts due to their lack of correctness towards other pupils.

\section{Conflict resolution methods in physical education depend- ing on a teacher's gender}

We also analysed the conflict resolution methods employed depending on a teacher's gender.

Of 17 questions in total, five revealed statistically significant gender related differences (TABLE 4). Those differences occurred at: dangerous situations in the pedagogical process, in situations when pupils don't follow the instructions, in situations when pupils have different interests, in situations where a pupil refused to perform a specific exercise and when a pupil disturbed the lesson with talking or inappropriate commentary.

Statistically significant differences between male and female physical education teachers were identified in terms of resolving a potentially dangerous situation (TABLE 4). The decision to resolve conflicts using the strategy of "insisting on one's own opinion" is applied by nearly the same percentage of male physical education teachers $(46.4 \%)$ as female ones $(53.6 \%)$. The "compromise" strategy to resolve dangerous situations is mainly chosen by male teachers ( $85.7 \%$ ); female teachers choose it less often (14.3\%). In terms of the most frequently chosen strategy among the four mentioned above, it was established (TABLE 1) that in dangerous situations both male and female teachers apply the method of "insisting on their own opinion" (71.79\% of male and $73.75 \%$ of female teachers). Given that both male and female teachers are aware of the potential con- sequences of pupils' dangerous activity during physical education classes, it is not surprising that this strategy is applied the most frequently.

As regards the hypothetical situation of "one group of pupils is interested in your proposal (e.g. the game featured in the programme), another wants something else and yet another wants something else again", the gender related differences in terms of selecting the conflict resolution strategy stem from the use of the "insisting on one's own opinion" strategy which is typical of male teachers. Interestingly, no female physical education teacher chose this strategy. They more often decided on the "compromise" (53.6\%) or "cooperation" $(52.6 \%)$ strategies. Male teachers choose "compromise" in $46.4 \%$ and "cooperation" in $47.4 \%$ of cases.

As regards the hypothetical situation of "the pupil refuses to perform a specific exercise", the gender related differences in terms of selecting conflict resolution strategies stem from the use of the "yielding" strategy which is, surprisingly, more frequently used by male physical education teachers. The female physical education teachers most often choose the "compromise" strategy.

Statistically significant gender related differences in terms of selecting a conflict resolution strategy were also identified within the hypothetical situation of "the pupil talks and comments during the explanation", where male teachers decide to adopt the strategy of "insisting on one's own opinion" (62.5\%), whereas their female counterparts prefer to use the "compromise" strategy $(72.7 \%)$.

\section{Conflict resolution methods in physical education}

Based on the responses to all questions and hypothetical situations in the questionnaire (dangerous and disturbing situations) the most frequently used conflict resolution methods were analysed (TABLE 5).

TABLE 5 shows the frequency of approaches to resolving conflict in physical education. Both male and female teachers most often use the authoritarian approach i.e. "the teacher insists on their opinion". Similar results have also been obtained by other Slovenian authors (Bežek, 2000).

\section{TABLE 4}

Conflict resolution methods in physical education depending on a teacher's gender

\begin{tabular}{|c|c|c|c|}
\hline Hypothetical situation & $\mathbf{X}^{2}$ & df & p \\
\hline The pupil intentionally moves to a place where other pupils can bump into them (provokes a dangerous situation) & 8.190 & 2 & 0.017 \\
\hline The pupil does not follow the instructions & 8.022 & 2 & 0.018 \\
\hline $\begin{array}{l}\text { One group of pupils is interested in your proposal (e.g. the game featuring in the programme), another wants } \\
\text { something else and yet another wants something else again }\end{array}$ & 8.653 & 2 & 0.013 \\
\hline The pupil refuses to perform a specific exercise & 10.761 & 3 & 0.013 \\
\hline The pupil talks and comments during the explanation & 14.109 & 3 & 0.003 \\
\hline
\end{tabular}

Legend: $\mathrm{X}^{2}=\mathrm{Chi}^{2}$ coefficient, $\mathrm{Df}=$ degree of freedom, $\mathrm{P}=$ statistical significance 
TABLE 5

Frequency of selecting individual conflict resolution styles

\begin{tabular}{|l|c|c|c|c|}
\cline { 2 - 5 } \multicolumn{1}{c|}{} & \multicolumn{2}{c|}{ Male teachers } & \multicolumn{2}{c|}{ Female teachers } \\
\hline Conflict resolution method & Number of responses & \% of responses & Number of responses & \% of responses \\
\hline The teacher insists on his/her own opinion & 460 & 53.62 & 410 & 46.59 \\
\hline The teacher yields & 22 & 02.56 & 16 & 01.82 \\
\hline The teacher seeks a compromise & 194 & 22.61 & 180 & 20.45 \\
\hline The teacher cooperates with the pupil & 182 & 21.21 & 274 & 31.14 \\
\hline Total & 858 & 100.00 & 880 & 100.00 \\
\hline
\end{tabular}

Legend: Number of male teachers -78 , Number of female teachers -80 , Number of questions -15

When choosing the most appropriate conflict resolution strategy, teachers should consider the fact that they can (must) exploit the conflict as a possible educational influence on a pupil (Brajša, 1993; Longaretti \& Wilson, 2006) and a motivational power for personal development (Kržišnik, 2004) of both the teacher and the pupil. The most efficient are those solutions which are not detrimental to any party in the conflict (Horvat, 1998; Tolar \& Katz Jameson, 2006; Lee, 2008; Narimani et al., 2008).

\section{DISCUSSION}

Conflict management requires the cooperation and coexistence of those who have found themselves in a conflict situation; therefore, it is necessary to know how to distinguish between dealing with a conflict and managing a conflict. Dealing with a conflict namely significantly affects its management (Brajša, 1993). If we learn how to successfully manage conflicts, we will have new opportunities for getting to know ourselves, other people and the world. The conflict management process itself enables more intense cooperation and strengthens relationships and at the same time brings with it new solutions, which are acceptable for all of the people involved. In the forefront of conflict management are the so called cooperative styles, which are related to positive results, while non-cooperative styles affect the negative results of the conflict, which has also been proven by numerous other studies (Bežek, 2000; Rahim, Magner, \& Shapiro, 2000; Štihec et al., 2009). The before mentioned non-cooperative styles include avoiding and dominating. Conflict resolution and the final solution depend on whether the relationships between the teacher and their pupils are good or bad, democratic or authoritarian. A key element of conflict resolution and consequences is the respective behaviour of the teacher and pupils in a given situation.

There are situations in physical education when pupils' behaviour can put them and other pupils in danger. In such situations, the teacher who is responsible for safety in the gym is therefore forced to employ domination in solving the conflict. Gordon (1992) believes that, when a fast and decisive reaction is required or when a large group of people is involved, the "power" method (whereby the teacher insists on their own opinion) is the only efficient one. Our results confirm this: in situations which could be dangerous the teachers mainly resort to resolving conflicts using the "insisting on one's own opinion" approach. There are no differences in between male and female teachers in such situations. Statistically significant differences between male and female physical education teachers were found in their choosing other strategies than "insisting on one's own opinion". More male teachers have chosen the "compromise" strategy. It is possible that male physical education teachers are more inclined to compromise solutions for resolving dangerous situations because they assess the same pedagogical situation differently (as being less dangerous) than their female counterparts.

In situations disturbing the pedagogical process the use of an authoritarian approach (whereby the teacher insists on their own opinion) probably saves time during a lesson, but the undesired behaviour may be repeated as the conflict may not necessarily be resolved (Bežek, 2000; Štihec et al., 2007). The authoritarian approach may also be efficient in such cases because, in principle, children are aware of the fact that their behaviour was unacceptable. The boisterous atmosphere and the nature of the physical education process characterised by a far more relaxed relationship between the teacher and the pupil can mislead pupils for a moment (Štihec, 1994). In such situations, a warning is enough to awaken the pupil and make them cooperate again. In this case, there is no deeper conflict at all. If the conflict lingers or becomes serious, the more successful method is usually where the teacher cooperates with the pupil (Horvat, 1998; Narimani, Agamohammadian, \& Ghaffari, 2008). This method saves more time in the long run. It also increases the probability that the conflict will be resolved in a quality way and the educational aspects of the democratic approach will be exploited (Gordon, 1992; Brajša, 1993; Longaretti \& Wilson, 2006). Our 
results showed that male teachers more often choose the domination strategy while female teachers choose the cooperation strategy when pupils disturbed lessons.

Related to consistency/inconsistency in the method chosen, the following should be considered. None of the surveyed teachers uses just one conflict resolution method. This does not translate into inconsistency since we anticipated that the choice of the approach also depends on the type of conflict behaviour (dangerous situation, disturbing the pedagogical process, different interests). Inconsistency in such a case is only involved when the teacher fails to take the same approach in similar situations. An example is when, in order to prevent a conflict behaviour, the teacher reacts in one way and the next time in a different way, depending on their mood. Based on our results we can say that female teachers in our survey are slightly more consistent than male teachers. Other authors have reported similar results with a Slovenian sample of physical education teachers (Bežek, 2000; Štihec et al., 2007).

Based on our results we can say that there are different pedagogical situations where statistically significant gender related differences in choosing a conflict resolution strategy have been found. Other authors have reported differences in choosing conflict resolutions as well. The chosen strategy can (as in our case) stem from gender (Havenga, 2008), the cultural environment (Hammer, 2005) or the teacher's target orientation (Somech, 2008). They are conditioned by our experience, emotional intelligence (Kajtna, 2006), leadership styles (Zabukovec \& Boben, 2000), etc.

\section{CONCLUSIONS}

The study aimed to establish which approaches to conflict resolution are used by physical education teachers in primary schools.

The results show that efficient conflict resolution in physical education requires the teacher to employ different approaches. The teachers mainly approach the resolving of conflict situations by "insisting on their own opinion". In the course of resolving a conflict, inconsistencies often occur but are mainly the consequence of the desire to ensure an efficient and the fastest possible elimination of the conflict behaviour.

It was also established that in some cases the male physical education teachers differed from their female counterparts in terms of which conflict resolution strategies they selected. People are different and react differently in various situations.

The teacher as an expert in the educational process can play a model role in a specific conflict. The teacher uses the situation as a useful educational means and affects the pupil with quality behaviour. This way pupils face and learn how to manage problems and conflicts and through them prepare themselves for future life, in which they will definitely encounter them. Of course, we should not forget that teachers are only human beings and that even they sometimes face a certain conflict situation for the first time, for which they cannot find a constructive and suitable manner of management at that very moment.

There are many factors involved in conflict resolution. In further research, some other factors, such as a teacher's age, cultural environment, a teacher's target orientation, a teacher's emotional intelligence, and leadership styles should be analysed.

\section{REFERENCES}

Anderson, J. W., Foster Kuehn, M., \& McKinney, B. C. (1996). Communication skills for surviving conflicts at work. New Jersey: Hampton Press, Inc. Cresskill.

Bežek, M. (2000). Reševanje konfliktnih situacij pri športni vzgoji [Conflict resolution in physical education]. Ljubljana: University of Ljubljana, Faculty of Sport.

Bjekić, D., \& Zlatić, L. (2006). Effects of professional activities on the teachers' communication competences development. In M. Brejc (Ed.), Cooperative partnerships in teacher education, Proceedings of the 31st annual ATEE conference (pp. 163-172). Ljubljana: National School for Leadership in Education.

Bowman, R. J. (2005). A comparison of two models used to predict student strategy choice for classroom conflicts. Kent State University.

Brajša, P. (1993). Pedagoška komunikologija [Pedagogical communicology]. Ljubljana: Glotta Nova.

Brajša, P. (1995). Sedem skrivnosti uspešne šole [Seven secrets of a successful school]. Maribor: Doba.

Deutsch, M. (1976). Konfliktregelung. Muenchen: Reinhardt.

Glasser, W. (1994). Kontrolna teorija. Kako vzpostaviti ucinkovito kontrolo nad svojim življenjem [Control theory. How to establish efficient control over one's life]. Ljubljana: Taxus.

Gordon, T. (1981). Familienkonferenz: die Losung von Konflikten zwischen Eltern und Kind. Reinbek bei Hamburg: Rowohlt Taschenbuch Verlag.

Gordon, T. (1992). Trening večje učinkovitosti za učitelje [Training teachers for better efficiency]. Ljubljana: Counselling Centre for Children, Adolescents and Parents.

Gross, M. A., \& Guererro, L. K. (2000). Managing conflict appropriately and effectively: An application of the competence model to Rahim's organizational conflict styles. The International Journal of Conflict Management, 11(3), 200-226. 
Hammer, M. R. (2005). The intercultural conflict style inventory: A conceptual framework and measure of intercultural conflict resolution approaches. International Journal of Intercultural Relations, 29, 675-695.

Havenga, W. (2008). Gender and age differences in conflict management within small businesses. Journal of Human Resource Management, 6(1), 22-28.

Horvat, M. (1998). Pomen konstruktivnega reševanja šolskih konfliktov. Pedagoška obzorja, 19(3/4), 152-159.

Kajtna, T. (2006). Psihološki profil vodilnih slovenskih športnih delavcev [Psychological profile of leading Slovenian sports workers]. Doctoral dissertation, University of Ljubljana, Faculty of Arts, Ljubljana.

Kržišnik, R. (2004). Medosebni konflikt kot gibalo osebnega razvoja [Interpersonal conflict as a motive power of personal development]. Human Resource Management Magazine, 2(5), 55-59.

Lee, K. L. (2008). En examination between the relationships of conflict management styles and employee's satisfaction. International Journal of Business and Management, 3(9), 11-25.

Longaretti, L., \& Wilson, J. (2006). The impact of perceptions on conflict management. Educational Research Quarterly, 29(4), 3-15.

Mahon, J. (2009). Conflict style and cultural understanding among teachers in the western United States: Exploring relationships. International Journal of Intercultural Relations, 33(1), 46-56.

Narimani, M., Agamohammadian, H. R., \& Ghaffari, M. (2008). The survey of the relationship of attachment styles and self efficacy to conflict resolution styles of sport coaches. Research Journal of Biological Sciences, 3(7), 704-709.

Rahim, M. A., Magner, N. R., \& Shapiro, D. L. (2000). Do justice perceptions influence styles of handling conflict with supervisors? What justice perceptions, precisely? International Journal of Conflict Management, 11(1), 9-31.

Robbins, S. P. (1989). Training in interpersonal skills. NY: Prentice Hall, Englewood. Cliffs.

Rus, V. S. (1994). Socialna psihologija. Teorija, empirija, eksperiment, uporaba [Social psychology. Theory, empirical aspect, experiment, use]. Ljubljana: Davean.

Somech, A. (2008). Managing conflict in school teams: The impact of task and goal interdependence on conflict management and team effectiveness. $E d u$ cational Administration Quarterly, 44(3), 359-390.

Štihec, J. (1994). Vloga in pomen komunikacije v pedagoškem procesu [Role and meaning of communication in the pedagogical process]. Śport, 42(4), 16-18.

Štihec, J., Bežek, M, Videmšek, M., \& Karpljuk, D. (2004). An analysis of how to solve conflicts of physical education classes. Acta Universitatis Palackianae Olomucensis. Gymnica, 34(1), 23-30.
Štihec, J., Videmšek, M., Karpljuk, D., Bežek, M., Šebjan, B., \& Vrbnjak, S. (2007). Consistency of selected methods for solving conflicts at classes of physical education. In N. Smajlović (Ed.), Zbornik naučnih i stručnih radova (pp. 465-468). Sarajevo: Univerzitet, Fakultet sporta i tjelesnog odgoja.

Tolar, L., \& Katz Jameson, J. (2006). Conflict styles and conflict transformation: Possibilities for new connection. In 19th annual conference of the International Association of Conflict Management. Montreal, Canada.

Zabukovec, V., \& Boben, D. (2000). Učitelji in stili vodenja [Teachers and leadership styles]. Ljubljana: Centre for Psychodiagnostic Tools.

Weitzman, E. A., \& Weitzman, P. F. (2000). Problem solving and decision making in conflict resolution. In M. Deutsch \& P. Coleman (Eds), The handbook of conflict resolution (pp. 185-209). San Francisco: Jossey-Bass.

\section{ANALÝZA ŘEŠENÍ KONFLIKTU゚ V TĚLESNÉ VÝCHOVĚ V ZÁVISLOSTI NA POHLAVÍ UČITELE \\ (Souhrn anglického textu)}

POZADÍ: V minulosti bylo provedeno mnoho studií zabývajících se řešením konfliktů, avšak pouze malé množství z nich se bliže zabývalo tělesnou výchovou. Specifická povaha práce $\mathrm{v}$ rámci tělesné výchovy $\mathrm{v}$ určitých situacích zvyšuje míru výskytu konfliktů. Učitel jako odborník v oblasti výchovného procesu v takových př́padech může být dobrým príkladem toho, jak zvládat daný konflikt.

CÍL: Studie byla zaměřena na shromažd’ování informací o rozdílných přístupech učitelů a učitelek tělesné výchovy při řešení konfliktních situací, jež se vyskytují v hodinách tělesné výchovy, se zaměřením na výběr strategií řešení konfliktů a jejich důslednou aplikaci.

METODY: K tomu účelu byl v dubnu roku 2010 proveden průzkum u 158 učitelů tělesné výchovy z náhodně vybraných slovinských základních škol (z toho 78 mužů a 80 žen ve věku 28-60 let). Učitelé $z$ vybraných škol se studie zúčastnili dobrovolně a jejich účast byla anonymní. Byl použit dotazník (Bežek, 2000; Štihec, Bežek, Videmšek, \& Karpljuk, 2004) se 17 otázkami. Byla spočtena četnost odpovědí. K prokázání toho, zda mezi učiteli a učitelkami tělesné výchovy existují rozdíly, pokud jde o výběr strategii řešení konfliktů, byl použit test $\chi^{2}$ při míře rizika $5 \%(\mathrm{p} \leq 0,05)$.

VÝSLEDKY: Bylo prokázáno, že učitelé používají různé metody řešení konfliktních situací. Nejčastěji používají autoritativní přistup („trvání na vlastním názoru“"). Statisticky významné rozdíly byly zjištěny mezi výsledky učitelů a učitelek tělesné výchovy v některých pedagogických situacích, pokud jde o výběr strategii řešení konfliktů. 
ZÁVĚRY: Učitelé k řešení konfliktních situací přistupují především tak, že „trvají na svém názoru“. Při řešení konfliktu se často vyskytuje nedůslednost, která je však ve velké míre důsledkem touhy nalézt efektivní a co nejrychlejší řešení konfliktního chování. Bylo také prokázáno, že v některých případech se učitelé tělesné výchovy odlišovali od svých ženských protějškủ v tom, jaké strategie řešení konfliktů zvolili. $V$ dalším výzkumu je možné se zaměřit na analýzu některých jiných faktorů, jako je např́iklad věk učitele, kulturní prostředí, cílová orientace učitele, jeho emoční inteligence a styl vedení.

Klíčová slova: základní škola, tělesná výchova, konflikty, učitelé a učitelky tělesné výchovy.

\section{Ass. prof. Jože Štihec, Ph.D.}

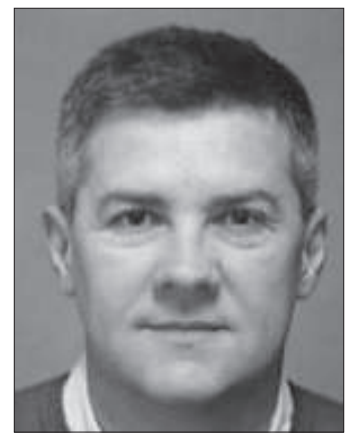

University of Ljubljana

Faculty of Sport

Gortanova 22

1000 Ljubljana

Slovenia

Education and previous work experience 1981-1985 - Master study - Faculty of Sport. 1985-1988 - Postgraduate study - Faculty of Sport. 1988-1991 - Ph.D. study - Faculty of Sport. Works as head of the Department of sport pedagogy at Faculty of Sport in Ljubljana. His research activities are focused at sport pedagogy, sport didactics and information and communication technology at physical education and sport.

\section{First-line publications}

Štihec, J., Karpljuk, D., Videmšek, M., \& Kondič, M. (2000). How do Slovene fourth grade primary schools students spend their summer holidays? International journal of physical education, 37(2), 70-74.

Štihec, J. (2001). Computer as a didactic aid in the process of physical education in school. Acta Univ. Carol., Kinanthropol., 37(1), 33-46.

Štihec, J., Ismajlovič, V., Videmšek, M., Karpljuk, D., Kompán, J., Pupiš, M., \& Nemec, M. (2009). Physical education and dance as elective subjects in Slovenian primary schools. In M. Videmšek, J. Štihec, D. Karpljuk, J. Kompán, M. Pupiš, M. Nemec, \& Ž. Jankovská (Eds.), Sport and physical education of the youth (1st ed.) (pp. 91-111). Banská Bystrica: Univerzita Mateja Bela, Fakulta humanitných vied.

Štihec, J., Bežek, M., Videmšek, M., Karpljuk, D., Kompán, J., Pupiš, M., \& Nemec, M. (2009). Solving conflicts at physical education classes. In M. Videmšek, J. Štihec, D. Karpljuk, J. Kompán, M. Pupiš, M. Nemec, \& Ž. Jankovská (Eds.), Sport and physical education of the youth (1st ed.) (pp. 159-175). Banská Bystrica: Univerzita Mateja Bela, Fakulta humanitných vied.

Štihec, J., Kondrič, M., Videmšek, M., Karpljuk, D., \& Pupiš, M. (2009). The role of sports students in developing a computer based sports knowledge base. In M. Kondrič, G. Furjan-Mandić, \& G. Munivrana (Eds.), International science congress: Table tennis and the aging population (pp. 132-139). Zagreb: European Table Tennis Union, Croatian Table Tennis Association, University of Zagreb: Faculty of Kinesiology, Faculty of Sport, Ljubljana. 